\title{
Jenny Pearce (ed.): Participation and Democracy in the Twenty-First Century City
}

\author{
Palgrave Macmillan, Houndmills, Basingstoke and New York, \\ 2010, pp. xiv +263 , index, $\$ 90.00$
}

\author{
Sylvia I. Bergh
}

Published online: 16 October 2010

(C) The Author(s) 2010. This article is published with open access at Springerlink.com

This edited volume brings together six urban case studies (three in the UK and three in Latin America) that together try to "draw out the potentialities, record the transforming moments as well as recognise the limitations of new participation spaces" (p. 252). While it is not a comparative study, the volume claims to "offer insight into the conditions which make participation feasible, self-generating, meaningful and progressive and which do not" (p. 253). This book is the product of a two-year research project entitled "Municipal Innovations in Non-Governmental Public Participation UK/Latin America", funded by the UK's Economic and Social Science Research Council. The editor is Professor of Latin American Politics and Director of the International Centre for Participation Studies in the Department of Peace Studies, University of Bradford. While many of the contributors also have predominantly academic backgrounds, several of them have been involved in local governance initiatives as activists or even councillors. Indeed, the whole research project was based on the participatory methodology of co-producing knowledge with the groups that were studied in each city. This entailed recognizing the different forms of knowledge (experiential as well as academic) and continuously sharing and debating emergent ideas during and after the field research. This led, at least in some cases, to greater ownership of the findings by local agents of change, though the methodology chapter is also very candid about the shortcomings of this approach. The cities (Porto Alegre, Medellín, Caracas, Manchester, Bradford, and Salford) were chosen as case studies as they constitute experiments that "mostly originate from the existing status quo, rather than from efforts to fill a power vacuum when the old order breaks down, unlike most participatory experiments in modern history" (p. 2).

Book review editor: Silvia Ferreira.

\section{S. I. Bergh $(\bowtie)$}

International Institute of Social Studies, Erasmus University Rotterdam,

The Hague, The Netherlands

e-mail: bergh@iss.nl 
The Introduction and Conclusion chapters provide useful reviews of the literature on (local) democracy and representation, participation, governance, and civil society. The case studies are presented as illustrating experiments with "participatory democracy" (for the Latin American cases) and "participatory governance", which offered "controlled inclusion" (in the case of the UK cities). The latter form of participation is based on a logic to "selectively include and foster relationships which accommodate to, rather than challenge, decision makers" (p. 237). The concepts of leadership, citizenship, and autonomy versus co-optation of community actors would have merited much more in-depth discussion to arrive at sharper and shared definitions, as they proved to be crucial variables in explaining different outcomes across the cases.

This book addresses very well the project's two central research questions, i.e., the way non-governmental public actors made use of new spaces of participation at the municipal level and how they interacted with governmental actors, and whether these innovations have enabled citizens who have disengaged from formal politics to engage meaningfully in ways which deepen democracy (p. ix). The detailed case studies include rich qualitative data and quotes from interviews, convincingly illustrating "the deficits in representative democracy, [and capturing] the difficult journey of building an alternative" (p. 28). The stories are told against the background of competing ideological frameworks of neo-liberalism, social market capitalism, and anti-capitalism, as well as the cities' individual histories and relationships with national governments and the influence of globalization. In particular, many of the case studies point to the (dynamic) tension between the institutions of representative democracy (such as elected councillors on local governments) and new participatory institutions populated by civil society "representatives" (such as participatory budgeting fora) that also claim popular legitimacy. However, this book falls short of comprehensively evaluating the concrete outcomes of these new participatory spaces. While the preface states as one of the research questions, "to what extent did these new spaces of participation contribute to more effective approaches to poverty, exclusion and conflict [..]?" (p. ix), the case studies do not provide systematic evidence to measure this extent beyond citing some anecdotal evidence, let alone deal with the problem of attribution.

Nevertheless, this book is highly relevant for both practitioners and scholars interested in local governance innovations, as it goes beyond the well-known Porto Alegre case and competently illustrates how many of the issues we commonly consider typical for developing countries in constituting barriers to participation (e.g., clientelism, community gatekeepers, limited capacity to reason publicly, "militant particularism", etc.) in fact also exist in Europe, and most probably, everywhere. In providing a detailed analysis of the conditions for meaningful participation, this book makes a significant contribution to establishing participation as a field of study.

Open Access This article is distributed under the terms of the Creative Commons Attribution Noncommercial License which permits any noncommercial use, distribution, and reproduction in any medium, provided the original author(s) and source are credited. 